\title{
Follow-up of HTLV-1 positive individuals in the GIPH cohort (1997-2013): Proviral load was not a prognostic marker for HAM/TSP
}

\author{
Poliane C Gonçalves ${ }^{1}$, Gabriela S Freitas ${ }^{1,2^{*}}$, Luiz CF Romanelli', Fernando A Proietti ${ }^{1}$, Anna B Carneiro-Proietti ${ }^{1}$, \\ Marina L Martins ${ }^{1}$
}

From 16th International Conference on Human Retroviruses: HTLV and Related Viruses

Montreal, Canada. 26-30 June 2013

\section{Background}

HTLV-1 proviral load (PVL) is considered a risk marker for diseases.

\section{Methods}

Quantification of HTLV-1 PVL was performed in 151 samples of 38 asymptomatic carriers (AC) collected at different times during follow-up (6.1 to 14.8 years, mean $10)$ and in samples of five individuals who developed HAM/TSP during follow-up (2.6 to 11.3 years, mean 7.2). We used SYBR Green and number of proviral copies/ 10,000 cells. Fluctuation of proviral load level was defined at $0.5 \log$ or more.

\section{Results}

PVL was stable in 52.6\% (20/38) and floated in $47.4 \%$ $(18 / 38)$ subjects. In AC, the median of PVL in the 1st sample was 85 and in the last $59(\mathrm{p}=0.59)$. Among those individuals with low PVL who showed fluctuation, it remained low (£1\%) in $77.8 \%$. In $60 \%$ with high PVL who showed fluctuation, it remained high during follow-up. 10 patients developed HAM/TSP during the follow-up, and PVL was quantified before and after in 5 cases. Median of PVL in the 1st sample was 445 , and in the last sample $98(\mathrm{p}=0.56)$. In all cases, PVL was higher in the asymptomatic period, declining after onset of HAM/TSP.

\section{Conclusions}

PVL reaches a plateau, characteristic of each individual; high PVL appears to be followed by decrease and stabilization in

\footnotetext{
* Correspondence: gabrielaaseabra@gmail.com

'GIPH (Interdisciplinary HTLV Research Group); Hemominas, Belo Horizonte, Minas Gerais, Brazil

Full list of author information is available at the end of the article
}

lower levels. Although PVL is supposedly a risk marker for HAM/TSP, it had modest prognostic value in our cohort; changes in clinical status and PVL did not coincide, besides occurrence of high stable PVL in AC. Hemominas/FAPEMIG/DECIT/MS.

\section{Authors' details}

'GIPH (Interdisciplinary HTLV Research Group); Hemominas, Belo Horizonte, Minas Gerais, Brazil. 'Faculdade da Saúde e Ecologia Humana (FASEH), Vespasiano, Minas Gerais, Brazil.

Published: 7 January 2014

\section{doi:10.1186/1742-4690-11-S1-P23}

Cite this article as: Gonçalves et al:: Follow-up of HTLV-1 positive individuals in the GIPH cohort (1997-2013): Proviral load was not a prognostic marker for HAM/TSP. Retrovirology 2014 11(Suppl 1):P23.
Submit your next manuscript to BioMed Central and take full advantage of:

- Convenient online submission

- Thorough peer review

- No space constraints or color figure charges

- Immediate publication on acceptance

- Inclusion in PubMed, CAS, Scopus and Google Scholar

- Research which is freely available for redistribution

Submit your manuscript at www.biomedcentral.com/submit
C Biomed Central 